\title{
Efektivitas Pemberian Terapi Musik Klasik Terhadap Penurunan Intensitas Nyeri Pada Pasien Post Sectio Caesarea Di Ruang Flamboyan 1 RSUD Salatiga
}

\author{
Novadhila Purwaningtyas ${ }^{1}$, Masruroh, S.SiT.,M.Kes ${ }^{2}$ \\ ${ }^{1,2}$ D-IV Kebidanan, Fakultas Ilmu Kesehatan, Universitas Ngudi Waluyo \\ e-mail : novadhila49@gmail.com \\ vinamasruroh@yahoo.co.id
}

\begin{abstract}
ABSTRAK
Nyeri merupakan masalah yang paling mendominasi pada pasca pembedahan section caesarea.Terapi musik klasik merupakan salah satu metode non farmakologi dengan teknik relaksasi. Di RSUD Salatiga penatalaksanaan nyeri menggunakan teknik farmakologi yaitu pemberian analgesik dan teknik non farmakologi yang digunakan untuk mengurangi nyeri adalah teknik nafas dalam dan belum pernah menggunakan terapi musik untuk mengurangi nyeri pada pasien post operasi Caesar. Untuk mengetahui efektifitas pemberian terapi musik klasik terhadap intensitas nyeri pada pasien post section caesarea Penelitian ini menggunakan pre eksperimental dengan pendekatan pre test and post test design. Teknik pengambilan pada penelitian ini menggunakan purposive sampling dengan jumlah sampel penelitian sebanyak 15 ibu post section caesarea . Uji analisis menggunakan uji statistik paired sample T test. Hasil peneltian diperoleh rata-rata umur responden 29 tahun dengan pendidikan sebagian besar SMP, rata-rata nyeri sebelum diberikan intervensi sebesar 7,60 dan sesudah diberikan intervensi sebesar 5,73. Ada perbedaan signifikan intensitas nyeri sebelum dan sesudah diberikan terapi musik klasik ( $P$ value 0,000 ). Secara statistik pemberian terapi music klasik dapat menurunkan intensitas nyeri pada pasien post section caesarea $(P$ value 0,000$)$.
\end{abstract}

\section{Kata Kunci : Terapi musik klasik, Intensitas Nyeri, Post Sectio caesarea}

\begin{abstract}
The Effectiveness of Giving Music Therapy to Decreasing Pain Intensity in Post-Caesarean Sectio Patients in Flamboyan Room 1 Salatiga Hospital

Pain is the most dominant problem in post perative section caesarea. Classical music therapy is one of the non-pharmacological methods with relaxation techniques. In Salatiga regional hospital accident management uses pharmacological techniques, namely analgesic administration and nonpharmacological techniques used to reduce pain are deep breathing techniques and have never used music therapy to reduce treatment in post cesarean patients. To find out the effectivity of classical music therapy toward decreasing pain intensity to post sectio caesarea patient. This research used pre-experimental with a pre-test and post-test design. The sampling technique in this research used
\end{abstract}


a purposive sampling with a total sample of 15 mothers post section caesarea. Test analysis used a statistical paired sample $T$ test. The results of the study obtained an average age of 29 years of respondents with the education of most junior high schools, the average pain before intervention was 7.60 and after intervention was 5.73. There was a significant difference of pain intensity before and after being given classical music therapy (P value 0,000). Statistically the provision of classical music therapy can reduce pain intensity in post section caesarean patients ( $P$ value 0,000).

Keywords $\quad$ : Classical Music Therapy, Pain Intensity, Post Section Casarea

\section{PENDAHULUAN}

Setiap ibu berharap persalinannya berjalan normal, tetapi tidak jarang proses persalinan mengalami keadaan gawat darurat dan masalah medis yang mengharuskan ibu menjalani tindakan operasi caesar. Sectio Caesarea (SC) merupakan tindakan pembedahan untuk melahirkan janin melalui insisi di dinding abdomen dan dinding uterus (Leveno, et al, 2009). Persalinan secara section caesarea sering mengalami rasa nyeri akibat insisi abdomen. Nyeri merupakan masalah yang paling mendominasi pada pasca pembedahan SC (Bobak et al,2004). Menurut International Associaion for the Study of Pain dalam NANDA NIC-NOC 2015 nyeri adalah pengalaman sensori dan emosional yang tidak menyenangkan yang muncul akibat kerusakan jaringan yang actual atau potensial atau digambarkan dalam hal kerusakan sedemikian rupa.

Persalinan secara section caesarea sering mengalami rasa nyeri akibat insisi abdomen. Nyeri merupakan masalah yang paling mendominasi pada pasca pembedahan SC (Bobak et al,2004). Nyeri pasca bedah merupakan satu dari masalah keluhan pasien tersering di rumah sakit sebagai konsekuensi pembedahan yang tidak dapat dihindari. Berdasarkan hasil penelitian rasa nyeri yang timbul setelah operasi dinding abdomen adalah nyeri ringan $25 \%$ dari 14 pasien, nyeri sedang $48,2 \%$ sebanyak 27 pasien, dan nyeri berat $26,8 \%$ dengan 15 pasien (Fitri, Trisyani \& Maryati, 2012).Nyeri dapat mengakibatkan berbagai masalah pada ibu mapun bayi. Dampak nyeri terhadap ibu yaitu Activity Daily Living (ADL) atau aktivitas seharihari dan mobilisasi ibu menjadi terbatas sehingga dari kurangnya perwatan bayi oleh ibu ( Purwandari 2009 dalam Kristiani \& Latifah 2013).

Menurut WHO (World Health Organization, 2015), angka kejadian Sectio Cesarea (SC) meningkat di negara-negara berkembang. WHO menetapkan indikator persalinan SC 5-15\% untuk setiap negara, jika tidak sesuai indikasi operasi SC dapat meningkatkan resiko morbiditas dan mortalitas pada ibu dan bayi. Angka kelahiran SC di Indonesia selalu mengalami peningkatan setiap tahunnya. Hasil Riskesdas tahun 2013 menunjukan kelahiran dengan metode operasi SC sebesar 9,8\% dari total 49.603 kelahiran sepanjang tahun 2010 sampai dengan 2013, dengan proporsi tertinggi di DKI Jakarta $(19,9 \%)$ dan terendah di Sulawesi Tenggara (3,3\%). Jawa Tengah memiliki angka proporsi 
bedah Caesar di atas rata-rata proporsi nasional yaitu 9,9\%. Secara umum pola persalinan melalui operasi Caesar menurut karakteristik menunjukkan proporsi tertinggi pada kuantil indeks kepemilikan teratas $(18,9 \%)$, tinggal di perkotaan $(13,8 \%)$, pekerjaan sebagai pegawai $(20,9 \%)$ dan pendidikan tinggi $(25,1 \%)$.

Metode penatalaksanaan nyeri mencakup pendekatan farmakologis dan non farmakologis. Metode pereda nyeri non farmakologis biasanya dipilih karena memiliki resiko yang sangat rendah. Salah satu distraksi yang sangat efektif adalah distraksi audio yaitu menggunakan musik, yang dapat menurunkan nyeri fisiologis, stress, dan kecemasan dengan mengalihkan perhatian seseorang dari nyeri ( Kevin A.P, dkk ,2016). Terapi musik telah diakui sebagai salah satu bentuk terapi pelengkap (Complementary Therapy) disamping akupuntur dan massage therapy, selain memiliki aspek estetika, juga mempunyai efek terapeutik sehingga musik banyak digunakan untuk membantu penyembuhan, menenangkan dan memperbaiki kondisi fisiologis (Halim 2005 dalam Nanik Handayani 2011).

Menurut Journal of the America Association for Music Therapist yang dikutip dalam Hendro dkk, (2015), menyatakan bahwa musik dan nyeri memiliki persamaan penting yaitu bahwa keduanya bisa digolongkan sebagai input dan output sensor. Sensori input berarti bahwa ketika musik terdengar, sinyal dikirim ke otak ketika rasa sakit dirasakan. Jika getaran musik dapat dibawa ke dalam resonansi dekat dengan getaran rasa sakit, maka presepsi psikologis rasa sakit akan diubah dan dihilangkan.

Terapi musik telah diakui sebagai salah satu bentuk terapi pelengkap (Complementary Therapy) disamping akupuntur dan massage therapy, selain memiliki aspek estetika, juga mempunyai efek terapeutik sehingga musik banyak digunakan untuk membantu penyembuhan, menenangkan dan memperbaiki kondisi fisiologis (Halim 2005 dalam Nanik Handayani 2011).

Mendengarkan musik dapat memproduksi zat endorphins (substansi sejenis morfin yang dapat mengurangi rasa sakit/nyeri) berperan dalam menghambat transmisi impuls nyeri disistem saraf pusat, sehingga sensasi nyeri dapat berkurang. Musik juga bekerja pada system limbik yang akan dihantarkan kepada system syaraf untuk mengatur kontraksi otot-otot tubuh, sehingga dapat mengurangi kontraksi otot (Potter \& Perry, 2009). Pada keadaan rileks tubuh akan distimulasi untuk memproduksi endorphin yang bereaksi menghilangkan rasa sakit, menimbulkan rasa tenang dan pada akhirnya akan merangsang organorgan tubuh untuk mereproduksi selsel yang rusak akibat pembedahan (Smeltzer et al, 2008).

Penelitian yang dilakukan oleh Astuti dan Merdekawati (2016) terapi musik klasik diberikan pada responden selama 15 menit pada ibu post section caesarea $<24$ jam dalam keadaan sadar, 7 jam setelah pemberian analgetik. Pengukuran skala nyeri menggunakan lembar instrument Numerical Rating Scale (NRS) dengan hasil penelitian diketahui bahwa adanya selisih nilai mean skala nyeri 1,72 dan standar 
deviasi 0,419. Hasil uji statistik didapatkan nilai P-value 0,002 , maka dapat disimpulkan ada pengaruh terapi musik klasik terhadap penurunan tingkat skala nyeri.

Penelitian dengan judul pengaruh terapi musik terhadap nyeri post operasi open reduction and internal fixation (Orif) di RSUD DR.H.Abdul Moeloek provinsi lampung didapatkan hasil ada pengaruh yang signifikan terapi musik dengan penurunan tingkat nyeri post operasi ORIF dengan ( $p$ value $=0,00$ dan $a=0,05$ ) (Novita, 2012). Dalam sebuah penelitian yang dilakukan oleh Jona, Widodo dan Shobirun (2010) intensitas nyeri sebelum di berikan terapi musik klasik adalah nyeri sedang dengan skala 4-6 (100\%), setelah diberikan terapi musik klasik intensitas nyeri adalah $59,1 \%$ nyeri sedang dan $40,9 \%$ nyeri ringan dengan hasil man whitney menunjukan nilai $\mathrm{p}=0,213$ ( $p>0,05)$, hal ini dikarenakan terapi musik klasik dapat merangsang tubuh mengeluarkan opoid endogen yaitu endorphin dan enkefalin yang memiliki sifat seperti morfin yaitu untuk mengurangi nyeri (Huges, 1975 dalam Ernawati dkk ,2010).

Menurut data rekam medis RSU Kota Salatiga (2018), jumlah bedah Caesar di RSUD Salatiga pada tahun 2016 sebanyak 562 kasus dari 1275 persalinan, tahun 2017 sebanyak 578 kasus dari 1543 persalinan dan tahun 2018 sebanyak 568 dari 1505 persalinan dimana pada bulan 2 terakhir sebesar 48 kasus caesar, dengan proporsi usia terbesar adalah usia antara 25-44 tahun dengan 35 kasus (73\%). Indikasi SC terbesar di RSUD Salatiga adalah prolonger pregnancy, dan Ketuban Pecah Dini (KPD).
Data dari hasil wawancara dengan 5 pasien post section caesarea kelas III di RSUD Salatiga diketahui bahwa pasien post section caesarea yang telah mendapatkan terapi anagesik, sebagian besar masih merasakan rasa sakit yang tidak tertahankan. Reaksi nyeri akibat pembedahan ginekologi ini diakui salah satu pasien post section caesarea sangat mengganggu kenyamanan bahkan tidak jarang pasien sampai menangis akibat nyeri yang dirasakannya. Data dari hasil wawancara dengan kepala bangsal ruang nifas mengatakan teknik non farmakologi yang digunakan untuk mengurangi nyeri adalah teknik nafas dalam dan belum pernah menggunakan terapi musik untuk mengurangi nyeri pada pasien post operasi Caesar.

\section{METODE PENELITIAN}

Jenis penelitian ini adalah pre eksperimental dengan pendekatan pre test and post test design. Penelitian dilakukan di RSUD Salatiga jalan Osamaliki No. 19 Kota Salatiga mulai dari tanggal 13 Juni 2019 sampai dengan 03 Juli 2019. Populasi dalam penelitian adalah ibu bersalin dengan Sectio Caesarea di RSUD jumlah sampel 15 responden dengan teknik purposive sampling. Analisis data yang digunakan yaitu analisis univariate dengan tendensi central dan analisis bivariate menggunakan uji statistic T-Test dependent karena data setelah dilakukan uji normalitas dengan hasil data berdistribusi normal dengan masing-masing $p$-value 0,052 dan $0,073>0,05$

\section{HASIL DAN PEMBAHASAN PENELITIAN HASIL PENELITIAN}


A. Analisis Univariat

1. Skala Nyeri Post Sectio Caesarea Sebelum diberikan Terapi Musik Klasik

Tabel 4.5 Distribusi Frekuensi Berdasarkan Skala Nyeri Sebelum Diberikan Terapi Musik Klasik Pada Pasien Post Sectio Caesarea di Ruang Flamboyan 1 RSUD Salatiga (n=15)

\begin{tabular}{ccccccc}
\hline Variabel & N & Mean & SD & Median & Min & Max \\
\hline Skala Nyeri & 15 & 7,60 & 0,828 & 8,00 & 6 & 9 \\
\hline Berdasarkan tabel 4.5 & & responden rata-rata nilai \\
dapat diketahui & bahwa & & skala nyerinya sebesar 7,60 \\
sebelum diberikan terapi & & dimana nilai terendah \\
musik klasik , dari 15 & & sebesar 6 dan tertinggi 9.
\end{tabular}

2. Skala Nyeri Post Sectio Caesarea Sesudah diberikan Terapi Musik Klasik Tabel 4.6 Distribusi Frekuensi Berdasarkan Skala Nyeri Sesudah Diberikan Terapi Musik Klasik Pada Pasien Post Sectio Caesarea di Ruang Flamboyan 1 RSUD Salatiga $(n=15)$

\begin{tabular}{ccccccc}
\hline Variabel & N & Mean & SD & Median & Min & Max \\
\hline Skala Nyeri & 15 & 5,73 & 0,884 & 6,00 & 4 & 7 \\
\hline
\end{tabular}

Berdasarkan tabel 4.6 dapat diketahui bahwa sesudah diberikan terapi musik klasik , dari 15 responden rata-rata nilai skala nyerinya sebesar 5,73 dimana nilai terendah sebesar 4 dan tertinggi 7 .

Tabel 4.8 Perbedaan Intensitas Nyeri Pasien Post Section Caesarea Sebelum Dan Sesudah diberikan Terapi Musik Klasik Di Ruang Flamboyan 1 RSUD Salatiga

\begin{tabular}{|c|c|c|c|c|}
\hline Variable & Perlakuan & $\mathbf{N}$ & Mean & p-value \\
\hline \multirow[t]{2}{*}{ Skala Nyeri } & Pretest & 15 & 7,60 & 20,546 \\
\hline & Posttest & 15 & 5,73 & 0,884 \\
\hline \multirow{2}{*}{\multicolumn{3}{|c|}{ Berdasarkan tabel 4.8}} & & maka dapat \\
\hline & & & & disimpulkan bahwa ada \\
\hline \multirow{2}{*}{\multicolumn{3}{|c|}{$\begin{array}{lrr}\text { dapat } & \text { diketahui } & \text { bahwa } \\
\text { sebelum } & \text { diberikan } & \text { terapi }\end{array}$}} & & perbedaan secara signifikan \\
\hline & & & & skala nyeri pasien post \\
\hline \multirow{2}{*}{\multicolumn{3}{|c|}{ musik klasik, rata-rata nilai }} & & section caesarea sebelum \\
\hline & & & & \multirow{2}{*}{$\begin{array}{l}\text { dan sesduah diberikan terapi } \\
\text { musik klasik }\end{array}$} \\
\hline \multicolumn{2}{|c|}{ skala nyeri sebesar 7,60 , } & & & \\
\hline
\end{tabular}
terapi musik klasik menurun menjadi 5,73. Berdasarkan uji $\mathrm{t}$ dependen, didapatkan nilai t hitung sebesar 20,546 dengan $p$-value 0,000 . Oleh karena $p$-value $0,000<\mathrm{a}$
B. Analisis Bivariat

1. Efektivitas Pemberian Terapi Musik Klasik Terhadap Penurunan Intensitas Nyeri Pada Pasien Post Sectio Caesarea

\section{PEMBAHASAN}

A. Gambaran Intensitas Nyeri Sebelum diberikan Terapi Musik Klasik Pada Pasien Post 
Sectio Caesarea di Ruang Flamboyan 1 RSUD Salatiga

Hasil penelitian ini menunjukkan bahwa rata-rata intensitas nyeri responden sebelum diberikan terapi musik klasik adalah 7,60, dengan skala nyeri terendah 6 dan skala nyeri tertinggi 9. Skala nyeri sebelum diberikan terapi musik klasik didapatkan hasil mayoritas nyeri berat (skala 7-10) sebanyak 14 responden $(93,3 \%)$ dan nyeri sedang (skala 4-6) sebanyak 1 responden $(6,67 \%)$. Hal ini di sebabkan karena nyeri pada post section caesarea diakibatkan dari robeknya lapisan kulit dan jaringan dibawahnya akibat pembedahan. Ketika suatu jaringan mengalami cedera, atau kerusakan mengakibatkan dilepasnya bahan-bahan yang dapat menstimulus reseptor nyeri seperti serotonin, histamine, ion kalium, bradykinin, prostaglandin, dan substansi $P$ yang akan mengakibatka respon nyeri (Kozier dkk, 2010).

Selain nyeri karena proses pembedahan nyeri pada pasien juga disebabkan oleh kecemasan pasien terhadap dirinya sendiri yang dapat meningkatkan presepsi nyeri. Hal yang sama juga dikemukakan oleh LeMone dan Burke (2008) bahwa kecemasan dapat meningkatkan presepsi nyeri, dan nyeri sebaliknya dapat menyebabkan kecemasan. Jika seseorang mengalami cemas berat, maka nyeri yang dirasakan lebih hebat (Matassarin-Jacobs dalam Harsono 2009). Hasil penelitian ini menunjukkan bahwa intensitas nyeri pasca operasi sebelum diberikan terapi musik juga disebabkan karena usia < 20 tahun sebanyak 1 responden dengan skala nyeri 9 yang termasuk dalam kategori nyeri berat. Hal ini disebabkan karena pada usia <20 tahun secara psikologis merupakan usia yang belum matang dan belum siap menerima keadaannya,

Nyeri yang dirasakan ibu post partum dengan section caesarea berasal dari robekan lapisan kulit dan jaringan dibawahnya akibat pembedahan (Vascopoulos \& Lerna, 2010). Kerusakan sel akibat pembedahan section caesarea mengakibatkan pelepasan neurotransmitter eksitatori seperti prostaglandin, bradykinin, kalium, histamine, dan substansi $P$ yang mengakibatkan sensasi nyeri ( Kyranou \& Puntillo, 2012). Nyeri biasanya terjadi pada 6 jam pertama sampai 36 jam setelah pembedahan dan menurun pada hari ketiga post section caesarea ( Kozier, 2010 dalam Fitri Andarni, 2012). Untuk mengurangi rasa nyeri tersebut, dapat diberikan terapi farmakologis dan terapi non farmakologis dalam membantu pasien mengelola nyeri.

Hasil penelitian ini menunjukkan bahwa intensitas nyeri pasca operasi sebelum diberikan terapi musik juga disebabkan karena usia $<20$ tahun sebanyak 1 responden dengan skala nyeri 9 yang termasuk dalam kategori nyeri berat. Hal ini disebabkan karena pada usia <20 tahun secara psikologis merupakan usia yang belum matang dan belum siap 
menerima keadaannya, penelitian ini didukung teori dari Yezierski (2012) usia berpengaruh terhadap sensitifitas nyeri yang disebabkan karena faktor fisiologi, perubahan biokimia dan perubahan mekanisme homeostatik dalam jalur somato sensorik yang berpengaruh terhadap pengolahan dan persepsi nyeri individu. Penelitian ini juga didukung oleh Rezki Ramadhani (2014) bahwa usia < 20 tahun tidak ada yang berada pada kategori nyeri ringan, melainkan berada pada kategori nyeri berat, sehingga ada pengaruh antara usia dengan nyeri post section caesarea.

Hasil penelitian ini juga menunjukkan bahwa intensitas nyeri pasca operasi pada responden dengan tingkat pendidikan akhir SD sebanyak 2 responden dengan skala nyeri 7 dan 8 yang termasuk dalam nyeri berat , SMP sebanyak 7 orang dengan kategori nyeri berat sebanyak 6 orang (7-8) dan nyeri sedang 1 orang (skala 6), SMA dengan skala nyeri 7 sebanyak 4 orang $(26,7 \%)$ dan skala nyeri 8 sebanyak 2 orang $(13,3 \%)$ yang termasuk kategori nyeri berat. Sehingga secara statistik disimpulkan bahwa hasil penelitian ini menunjukkan tidak adanya kaitan antara respon nyeri dengan tingkat pendidikan. Hal ini sejalan dengan hasil penelitian yang dilakukan Harsono (2009) pada 85 pasien bedah seksio sesarea yang menunjukkan bahwa tidak ada hubungan yang signifikan antara intensitas nyeri dan tingkat pendidikan.
Dilihat dari teori bahwa tingkat pendidikan merupakan salah satu faktor yang menentukkan terhadap tejadinya perubahan perilaku, dimana semakin tinggi tingkat pendidikan pada seseorang, maka berarti telah mengalami proses belajar yang lebih sering, dengan kata lain tingkat pendidikan mencerminkan intensitas terjadinya proses belajar (Notoatmodjo 2002 dalam Harsono 2009). Pada penelitian ini peneliti hanya melihat dari tingkat pendidikan responden, tanpa melihat apakah responden pernah atau tidak mengalami proses belajar tentang pengelolaan nyeri, karena kurangnya pemahaman terhadap sumber, hasil dan arti nyeri dapat berkontribusi secara negative terhadap pengalaman nyeri.

B. Gambaran Intensitas Nyeri Sesudah diberikan Terapi Musik Klasik Pada Pasien Post Sectio Caesarea di Ruang Flamboyan 1 RSUD Salatiga

Hasil penelitian menunjukkan bahwa rata-rata intensitas nyeri responden sesudah diberikan terapi musik klasik adalah 5,73 dengan skala terendah 4 dan skala nyeri tertinggi 7 . Rata-rata penurunan nyeri sebelum dan sesudah diberikan terapi musik klasik adalah 1-2 interval. Hal ini karena pada saat pemberian terapi musik klasik pasien merasa lebih rileks sehingga nyeri yang dirasakan berkurang. Penelitian ini juga didukung dengan teori dari Schou (2008) dalam Mahanani (2013) bahwa efek terapi musik klasik pada 
nyeri adalah distraksi terhadap pikiran tentang nyeri, menurunkan kecemasan, menstimulus ritme nafas lebih teratur, menurunkan ketegangan tubuh, memberikan gambaran positif pada visual imageri, relaksasi, dan meningkatkan mood yang positif. Terapi musik dapat mendorong perilaku kesehatan yang positif, mendorong kemajuan pasien selama masa pengobatan dan pemulihan.

Hasil penelitian lain yang dilakukan McCaffrey menemukan bahwa intensitas nyeri menurun sebanyak 33\% setelah terapi musik dengan menggunakan musik klasik Mozart terhadap pasien osteoarthritis selama 20 menit dengan musik Mozart (Jerrard 2004 dalam Harefa, Manurung, dan Nainggolan 2010).

Dr John Diamond dan Dr David Nobel telah melakukan riset mengenai efek dari musik terhadap tubuh manusia dimana merka menyimpulkan bahwa jenis musik yang kita dengar sesuai dan dapat diterima oleh tubuh manusia, maka tubnuh akan bereaksi dengan mengeluarkan sejenis hormone (serotonin) yang dapat menimbulkan rasa nikmat dan senang sehingga tubuh akan menjadi lebih kuat (dengan meningkatnya sistem kekebalan tubuh) dan membuat kita menjadi lebih sehat

Musik dan nyeri mempunyai persamaan, keduanya bisa digolongkan sebagai input dan output. Sensori input yaitu ketika musik mulai terdengar, sinyal musik akan dikirim ke otak saat rasa sakit mulai dirasakan. Jika getaran musik dapat dibawa kedalam persepsi di dalam psikologisya dari rasa nyeri akan hilang (Harefa, Manurung, dan Nainggolan 2010).

Hasil tersebut menunjukkan bahwa setelah pemberian terapi musik maka nyeri responden mengalami penurunan. Hal ini sesuai dengan penyataan dari Purwanto (2012) bahwa terapi musik mempunyai tujuan membantu mengekspresikan perasaan, membantu rehabilitasi fisik, memberikan pengaruh positif terhadap kondisi suasana hati dan emosi, meningkatkan memori serta menyediakan kesempatan yang unik untuk berinteraksi dan membangun kedekatan emosional, dengan demikian terapi music juga diharapkan dapat membantu stress, mencegah penyakit dan meringankan rasa sakit.

Penurunan tingkat nyeri sesudah diberikan terapi musik pada pasien post section caesarea terjadi karena hormone endrofin yang telah distimulus setah post op section caesarea yang memiliki efek mengurangi nyeri. hal ini di dukng oleh Chiang (2012) dalam Novita (2013) bahwa musik yang bersifat sedative terbukti efektif dalam mengurangi nyeri. mekanisme musik dalam menurunkan nyeri sebagaimana dijelaskan dalam teori Gate Control, dimana impuls music berkompetisi mencapai korteks serebri bersama dengan impuls nyeri akan berefek pada distraksi kognitif dalam inhibasi persepsi 
nyeri (Dunn 2004; Guss 2007 dalam Novita 2013).

Meskipun pada penelitian ini nyeri sebelum dan sesudah pemberian terapi musik klasik terjadi penurunan tetapi terdapat responden yang mengalami penurunan nyeri yang masih dalam kategori berat (skala nyeri 7), hal ini dapat dikaitkan dengan kondisi lingkungan karena peneliti melakukan intervensi pemberian terapi musik klasik pada saat jam kunjung yaitu jam 11.00-13.00 sehingga pemberian terapi musik klasik kurang maksimal karena pengunjung mengajak pasien bercerita tentang pengalaman melahirkannya. Hasil penelitian ini didukung dengan teori dari Potter \& Perry (2006) yaitu faktor yang mempengaruhi nyeri dibedakan menjadi dua yaitu faktor internal dan eksternal, salah satu dari faktor eksternal yaitu lingkungan dimana nyeri dapat diperberat dengan adanya rangsangan dari lingkungan seperti kebisingan atau cahaya yang sangat terang.

\section{Pengaruh Terapi Musik Klasik Terhadap Nyeri Pasien Post Sectio Caesarea di Ruang Flamboyan 1 RSUD Salatiga}

Hasil penelitian menunjukkan bahwa rata-rata nilai skala nyeri sebelum diberikan terapi musik klasik sebesar 7,60 , kemudian sesudah diberikan terapi musik klasik menurun menjadi 5,73. Berdasarkan uji paired t-test pada penelitian ini, didapatkan nilai $\mathrm{t}$ hitung sebesar 20,546 dengan p-value 0,000 . Oleh karena $p$-value $0,000<\mathrm{a}(0,05)$, maka dapat disimpulkan bahwa ada perbedaan secara signifikan skala nyeri pasien post section caesarea sebelum dan sesudah diberikan terapi musik klasik di Ruang Flamboyan 1 RSUD Salatiga. Hal ini disebabkan karena pemberian terapi musik dapat membuat seseorang menjadi rileks sehingga dapat menurunkan rasa sakit dan juga menurunkan tingkat stress yang dirasakan oleh pasien.

Cara kerja musik dapat mempengaruhi kondisi tubuh, antara lain menurunkan hormonhormon yang berhubungan dengan stress, mengalihkan perhatian seseorang dari rasa takut, cemas, dan tegang, mengaktifkan hormone endorphin (semacam protein yang dihasilkan didalam otak dan berfungsi untuk menghilangkan rasa sakit dan menyediakan "liburan mental mini" yang bahkan dapat membawa pikiran seseorang menjauh dari rasa sakit fisik selama periode waktu tertentu, secara fisiologis memperbaiki sistem kimia tubuh, sehingga mampu menurunkan tekanan darah serta memperlambat pernafasan, detak jantung, denyut nadi dan aktivitas gelombang otak (Aizid, 2011).

Hasil penelitian ini sejalan dengan hasil penelitian Shintadewi, Ruth Berliana (2011) dengan hasil nilai ratarata nyeri sebelum diberikan perlakuan 5,64 dengan standar deviasi 1,09 dan nilai rata-rata nyeri setelah diberikan perlakuan 3,79 dengan standar deviasi 1,62 dan dapat disimpulkan bahwa terapi musik berpengaruh signifikan terhadap 
penurunan intensitas nyeri post section caesarea dengan nilai $\mathrm{P}$ value 0,003

Hasil penelitian ini juga didukung penelitian dari Novita (2012) dengan judul pengaruh terapi musik terhadap nyeri post operasi open reduction and internal fixation (Orif) di RSUD DR.H.Abdul Moeloek provinsi lampung didapatkan hasil ada pengaruh yang signifikan terapi musik dengan penurunan tingkat nyeri post operasi ORIF dengan $(\mathrm{p}$ value $=0,00$ dan $\mathrm{a}=0,05)$. Hasil penelitian ini juga didukung penelitian dari Purwanto (2012) dengan hasil bahwa efek music dapat menurunkan intensitas nyeri dari nyeri berat ke nyeri ringan pada pasien post operasi di ruang bedah RSUP Dr.Sardjito Yogyakarta. Hasil penelitian ini diperkuat penelitian dari Oktavia, Gandamiharja dan Akbar (2013) dengan hasil bahwa didapatkan perbedaan yang bermakna antara nyeri sebelum dan sesudah mendengarkan musik klasik.

Menurut Potter dan Perry (2006) salah satu upaya mengatasi rasa nyeri adalah dengan memberikan tindakan non farmakologi. Teknik non farmakologi untuk mengurangi nyeri terdiri dari massage effleurage, teknik relaksasi dan teknik distraksi. Distraksi adalah memfokuskan perhatian pasien pada sesuatu hal atau melakukan pengalihan perhatian ke hal-hal diluar nyeri. distraksi dapat dilakukan dengan cara distraksi penglihatan (visual), distraksi intelektual (pengalihan nyeri dengan kegiatan-kegiatan), dan distraksi pendengaran (audio) (Andarmoyo, 2013).

Teori lain yang sejalan dengan konsep diatas adalah (Hartati dan Maryunani, 2015) bahwa teknik penanganan nyeri post section caesarea salah satunya adalah teknik relaksasi. Teknik relaksasi yaitu teknik dengan cara posisi tetap berbaring, tidak ada gerakan fisik, mata terpejam dengan mengendurkan dan melemaskan seluruh tubuh sambal menarik nafas dalam dari hidung dan mengeluarkannya pelan-pelan dari mulut selama 5-10 menit, mendengarkan musik, serta mencium aroma-aroma yang menenangkan. Musik merupakan sebuah rangsangan yang terorganisasi yang terdiri atas melodi, ritme, harmoni, timbre, bentuk dan gaya (Aizid, 2011). Terapi musik adalah terapi yang bersifat non verbal. Dengan bantuan musik dapat mengatasi stress, meningkatkan perasaan rileks, serta dapat meningkatkan hormone endorphin pada tubuh. Ketika musik diapliksikan menjadi sebuah terapi, maka ia dapat meningkatkan, memulihkan, serta memelihara kesehatan fisik, mental, emosional, sosial dan spiritual setiap individu (Aizid, 2011).

Hal tersebut juga sejalan dengan teori (Young \& Koopsen, 2007) bahwa musik digunakan untuk menjaga atau meningkatkan tingkat keadaan fisik, mental, spiritual serta fungsi sosial atau emosional klien. Dengan menggunakan pendekatan yang terencana dan sistematis terhadap penggunaan 
musik dan aktifitas musik, penanganan dengan terapi musik untuk jiwa, tubuh dan roh memungkinkan terjadinya seperti : pengurangan kegelisahan dan stress, pengendalian rasa sakit dan ketidaknyamanan dengan tanpa obat, perubahan positif dalam perasaan dan keadaan emosional, partisipasi aktif klien dalam perawatan, mengembangkan keterampilan menangani masalah dan berelaksasi, memenuhi kebutuhan fisik dan spiritual yang kompleks dari mereka yang butuh penanganan nyeri, relaksasi bagi seluruh keluarga, meningkatkan makna waktu yang digunakan bersama secara positif dan kreatif.

\section{PENUTUP}

\section{A. Kesimpulan}

1. Intensitas nyeri sebelum diberikan intervensi dari 15 responden rata-rata nilai skala nyerinya sebesar 7,60 dimana nilai terendah sebesar 6 dan tertinggi 9 .

2. Intensitas nyeri sesudah diberikan intervensi dari 15 responden rata-rata nilai skala nyerinya sebesar 5,73 dimana nilai terendah sebesar 4 dan tertinggi 7

3. Ada perbedaan yang signifikan intensitas nyeri sebelum dan sesudah diberikan terapi musik klasik.

\section{B. Saran}

1. Bagi Rumah Sakit

Terapi musik klasik terbukti dapat menurunkan intensitas nyeri pada pasien post operasi section caesarea.
Sehingga diharapkan terapi musik klasik dapat dipertimbangkan untuk diterapkan sebagai intervensi keperawatan dalam mengatasi respon nyeri pasien pasca operasi section caesarea.

2. Bagi Institusi Pendidikan

Hasil penelitian ini diharapkan dapat menambah wawasan dan pengetahuan mahasiswa yang lebih luas tentang terapi komplementer musik dalam penanganan respon nyeri.

3. Bagi Peneliti Selanjutnya Peneliti selanjutnya hendaknya menggunakan metode atau terapi yang lain dalam membantu menurunkan nyeri post section caesarea misalnya dengan menggunakan teknik distraksi audio visual, teknik relaksasi.

\section{DAFTAR PUSTAKA}

American Music Therapy Association (2009).

Definition and Quotes about Music Therapy http://www.musictherapy.org/ quotes. html (diakses tanggal 17 April 2019)

Andarmoyo, S. (2013). Konsep dan Proses Keperawatan Nyeri. Yogyakarta : Ar-Ruzz

Ani Astuti, Diah Merdekawati. (2016). Pengaruh Terapi Musik Klasik TerhadapPenurunan Tingkat Skala Nyeri Pasien Post Operasi.Volume 10No.3. http://dx.doi.org/xxxxx/JIT.2 
008.350-526. diakses pada tanggal 21 Januari 2019.

Black L.M. \& Hawk, J.H. (2014). Medical-surgical nursing clinical management for positive outcomes. ( $\left.7^{\text {th }} \mathrm{Ed}\right)$. St.Louis, Missouri : Elsevier Saunders

Brunton, L., K.Parker, D. Blumenthal, L. Buxton. (2008). Goodman \& Gilman's Manual of Pharmacology and Therapeutic. NewYork : McGrawHill

Bobak, IM, Lowdermilk, dl Jensen, MD \& Perry. (2004). Buku Ajar Keperawatan Maternitas Edisi 4. EGC : Jakarta.Companies,Inc.

Camphel, Neil A. (2009). Biologi Jilid 2 Edisi 5.Erlangga : Jakarta

Cunningham, dkk. (2012). Obstetri Williams volume 2 edisi 23. Jakarta: EGC

Dewi Y., dkk. (2007). Operasi Caesar, Pengantar dari A sampai Z. EDSA Mahkota. Jakarta

Djohan. (2006). Terapi Musik Teori dan Aplikasi. Yogyakarta : Galangpress

Dofi, Bellavia A. (2010). Psikologi Musik Terapi Kesehatan. Jakarta: Golden Terayon Press.

Ebneshahidi A ., Mohseni, M.(2008). The Effect of Patiens Selected
Music on Early pasca operative Pain Anxiety and Hemodinamic Profile in Cesarean Section Surgegy,Journal of Alternative and Complementary Medicine. Vol.14 No.7

Eka, Erwin .(2009). Pusat Riset Terapi Musik dan Gelombang Otak, Indonesia, http://www.terapimusik/2dese mber2013.com

Ernawati, Hartati dan Hadi. (2010). Terapi relaksasi terhadap nyeri disminore pada mahasiswi Universitas Muhammadiyah semarang. http://jurnal.Unimus.ac.id/ind ex.phppsn12012010/article/vi ew/54 diperoleh tanggal 14 maret 2019.

Fitri, Milla., Mira Trisyani., \& Ida Maryati. (2012). Hubungan Intensitas Nyeri Luka Sectio Caesarea dengan Kualitas Tidur pada Pasien Post Partum Hari ke-2 di Ruang Rawat Inap RSUD Sumedang. Bandung: FIK Universitas Padjajaran.

Good, M. et al., (2010). Supplementing Relaxion and Music For Pain After Surgery. July/august 2010, Vol 59, No 4.

Guyton, A.C., dan Hall, J.E. (2008). Buku Ajar Fisiologi Kedokteran. Edisi 11. Jakarta : EGC

Handayani, N. (2011). Pengaruh Terapi Musik Terhadap 
Tingkat Nyeri Pasien Pasca Operasi Seksio Sesarea Di Rs Islam Jl. A Yani Surabaya. Surabaya : STIKes Yarsis

Harsono. (2009). Faktor-Faktor Yang Mempengaruhi Intensitas Nyeri Pasca Bedah Abdomen Dalam Konteks Asuhan Keperawatan Di Rumah Sakit Umum Daerah Ade Mohammad Djoen Sintang. Depok : Fakultas Ilmu Keperawatan Universitas Indonesia

Hartati, S \& Maryunani, A.( 2015). Asuhan Keperawatan Ibu Post Seksio Sesarea : Pendekatan Teori Model Selfcare dan Comfort. Cetakan Pertama. Jakarta: Trans Info Media

Hidayat, Aziz Alimul. (2008). Keterampilan Dasar Praktik Klinik Kebidanan. Edisi 2. Jakarta: Salemba Medika.

Indiarti, MT. (2009). Panduan Lengkap Kehamilan, Persalinan dan Perawatan Bayi. Yogyakarta : Diglossia Media.

Ira Suarilah, Erna Dwi Wahyuni, Ryan Reza Falupi. (2014). Guided Imagery And Music (Gim) Menurunkan Intensitas Nyeri Pasien Post Sectio Caesarea Berbasis Adaptasi Roy. Surabaya : Fakultas Keperawatan Universitas Airlangga.

Katz, A.W. (2005).Cyclooxigenase2-selective inhibitors in the management of acute and Konsep, Proses \& Praktik,
Volume : 1, Edisi : 7, EGC : Jakarta

Kevin A. P. Here, Sakti O. Batubara Angela Maryati Gatum.(2017). Efektifitas Terapi Musik Klasik Terhadap Penurunan Intensitas Nyeri Pada Ibu Primipara Post Operasi Sectio Caesarea Di Ruang Flamboyan Rsud Prof. Dr. W. Z. Johannes Kupang.Kupang : Fakultas Keperawatan STIKes CHMK Kupang.

Kozier, B., \& Erb. (2004). Fundamentals of nursing, concepts, process, and practice.New Jersey : Pearson education Inc.

Kristiarini, D, dan Latifah, L. (2013). Pengaruh Teknik Relaksasi Autogenik Terhadap Skala Nyeri pada Ibu Post Operasi Sectio Caesarea (SC) di RSUD Banyumas. Skripsi. Universitas Jendral Soedirman.

Lemone, P., \& Burke, M.K. (2008). Medical-surgical nursing. Critical thingking clien care. New Jersey : Pearson education INC.

Leveno, KJ, Cunningham, FG, Gant, NF, Alexander JM, Bloom, SL, Casey BM, Dashe, JS, Shffield, JS \& Yost, NP. (2009). Panduan Ringkas Obstetri Williams, Edisi 21. Jakarta : EGC

Marmi, D. (2013). Intranatal Care Asuhan Kebidanan Pada 
Persalinan. Yogyakarta : Pustaka Pelajar

Novita, P. (2012). Pengaruh Terapi Musik Terhadap Nyeri Post Operasi Open Reduction And Internal Fixation (ORIF) Di RSUD DR. H Abdul Moeloek Propinsi Lampung. Tesis Universitas Indonesia, Depok

Notoatmodjo, S. (2010.) Metodologi Penelitian Kesehatan, Ed. Rev. Jakarta: Rineka Cipto

Nursalam. (2013). Metodologi Penelitian Ilmu Keperawatan. Jakarta: Salemba Medika

Oktavia, Gandamiharrja \& Akbar (2013). Perbandingan Efek Musik Klasik Mozart dan Musik Tradisional Gamlen Jawa terhadap Pengurangan Nyeri Persalinan Kala I fase Aktif Pada Nulipara. Universitas Padjadjaran, Vol.45, No.4

Potter,P.A.,\& Perry, A.G. (2010). Buku ajar fundamental keperawatan. (Buku 3 edisi 7). Jakarta: EGC.

Prawirohardjo, sarwono. (2009). Ilmu kebidanan. Jakarta : PT. Bina Pustaka

Rasjidi, Imam. (2009). Manual Seksio Sesarea \& Laparotomi kelainan Adneksa. Jakarta: Sagung Seto

Sari, P. dan Adilatri, S.A.(2012). Perbedaan Terapi Musik Klasik Mozart dengan Terapi Musik Kesukaan Terhadap Intensitas Nyeri Haid Pada
Remaja Putri Di SMA Negeri 5 Denpasar Tahun 2012. 84 http://ojs.unud.ac.id/index.ph p/coping/article/download/61 29/4620. Diakses pada tanggal 23 Januari 2019

Sari, P. A. R.(2014). Pengaruh Terapi Musik Klasik Terhadap Penurunan Nyeri Pada Pasien Post Operasi Sectio Caesarea di Bangsal Kenanga $R S U D$ Karanganyar: Stikes Kusuma Husada Surakarta

Sjamsuhidajat \& de jong.(2010). Buku Ajar Ilmu Bedah.Jakarta: EGC

(2012). Buku Ajar Ilmu Bedah.Jakarta: EGC

Smeltzer dan Bare. (2008). Buku Ajar Keperawatan Medikal Bedah. Jakarta : EGC

Sofian, A. (2011). Rustam Muchtar Sinopsis Obstetri. Jakarta : Buku Kedokteran EGC

Solehati, Tetti dan Cecep Eli Kosasih., (2015). Konsep dan Aplikasi Relaksasi dalam Keperawatan Maternitas. Bandung : PT. Refika Aditama.

Sugiyono. (2014). Metode Penelitian Kuantitatif Kualitatif dan $R \& D$. Bandung: Alfabeta

Swandari, P. (2014). Perbedaan Tingkat Nyeri Sebelum dan Sesudah Pemebrian Aromatherapi Lavender pada Ibu Post Sectio Caaesarea di 
RSUD

Ambarawa: STIKES Ngudi

Waluyo Ungaran

Tamsuri, A.(2007). Konsep dan Penatalaksanaan nyeri. Jakarta : EGC.

Zakiyah, Ana. (2015). Nyeri: Konsep dan Penatalaksanaan dalam Praktik Keperawatan Berbasis Bukti. Jakarta: Salemba Medika 